\title{
Problems in managing foreign bodies in the upper aerodigestive tract
}

\author{
Efiaty Arsyad Soepardi
}

\begin{abstract}
Abstrak
Aspirasi benda asing dan tersangkutnya pada esofagus lebih banyak terjadi pada anak-anak di bawah usia lima tahun. Khususnya untuk anak kecil, tersumbatnya jalan napas karena aspirasi benda asing dan tersangkutnya pada esofagus merupakan penyebab utama kematian akibat kecelakaan di rumah. Pada tingkat tertentu, penegakan diagnosis tetap merupakan suatu masalah besar terutama karena kesulitan dalam anamnesis, mendapatkan gejala dan tanda klinik yang jelas, dan menentukan tehnik pemeriksaaan radiology yang tepat. Oleh karena itu, di samping tersedianya peralatan yang lengkap, penatalaksanaan pada kasus-kasus ini nembutuhkan seorang ahli dan keterampilan profesional dalam bidang endoskopi. Makalah ini akan membahas tentang kesulitankesulitan yang terjadi pada penderita aspirasi benda plastik, dan kacang di saluran napas, seria batu dan gigi tiruan yang tersangkut di esofagus. (Med J Indones 2002; 11: 15-8)
\end{abstract}

\begin{abstract}
The incidence of foreign body aspiration and ingestion in esophagus is higher in children under five years old. Especially for young children, suffocation from inhalation and ingestion of foreign bodies represents the highest cause of home accidental death. To some extent, establishing the diagnosis of foreign body ingestion or aspiration remains a big problem due to some difficulties in taking the history, getting the accurate signs and symptoms and performing radiologic examination. Therefore, beside the availability of the necessary equipments, the management of these particular cases requires person with expertise and professional skill in endoscopy. This paper will discuss several problems happening to real patients in the case of aspirated plastic materials and peanut as well as stones and dentures that were stuck in the esophagus. (Med J Indones 2002; 11: 15-8)
\end{abstract}

Keywords: foreign body, esophagoscopy, bronchoscopy

Foreign body aspiration or ingestion in esophagus can occur to any person at any age. However, the majority of these accidents occurs in children under five years old. ${ }^{1,2,3}$ Suffocation due to foreign bodies aspiration is the leading cause of home accidental death and this is certainly becoming a challenge for otolaryngologist in conducting proper diagnosis and treatment. ${ }^{4}$ The big and round shape foreign body such as stone can produce airway obstruction.

In many cases, carelessness is a predisposing factor. ${ }^{1,2,3,4}$ Letting the habitual of hasty eating or drinking, allowing children to play or laugh while

Department of Otorhinolaringology, Faculty of Medicine University of Indonesia/Dr Cipto Mangunkusumo Hospital, Jakarta, Indonesia.

Presented in $9^{\text {th }}$ ASEAN ORL Head and Neck Congress, Singapore 2001 eating, and feeding babies while crying are the most common carelessness done by their caretakers or even their parents. Giving hard candies or nuts to children under three years old is also considerably dangerous since they lack molars for proper grinding. In many cases, lack coordination of swallowing and glottis closure often becomes the cause of aspiration. Furthermore, the children have also a tendency to put inedible objects in their mouth then trying to talk or laugh at the same time.

When aspirated, larger foreign body has a tendency to stuck in the larynx or trachea, whereas a small one will be lodged in the right or left bronchus. In the case of adults, the right main bronchus is the predilection site of obstruction.

It is not easy to establish the diagnosis not only due to radiolucent nature of some foreign bodies but also related to difficulties in taking the history and detecting symptoms in asymptomatic stage. .,3,5 $^{2}$ 
Many ingested foreign bodies were found in upper esophageal sphincter, including true foreign bodies and food-related foreign bodies. This is because the upper esophageal sphincter is the narrowest part of gastrointestinal tract.

\section{History}

In the case of small children, the history of foreign body is usually unclear. Older children are often reluctant to inform the details of the accident due to the embarrassment or the fear of punishment. Moreover, their parents are commonly not able to explain the precise history. The inaccurate history could lead to inappropriate and late diagnosis. A clear description is expected to comfort the patient.

Difficulty in swallowing and regurgitation is the main symptoms of foreign body ingestion in the upper esophagus. Most of the parents do not know the difference between regurgitation and vomiting. Regurgitation means rejecting food or water directly after swallowed, while vomiting means rejecting food or water after several minutes or more..

\section{Clinical examination}

Once a foreign body is aspirated, it will generally produce a clear signs and symptoms such as coughing, chocking gasping, and gagging, and they are known as initial laryngeal protection reflexes. When these reflexes are quited due to fatigue, the early symptom will disappear and the asymptomatic stage will begin. At this stage, the physicians do not realize about the possibility of foreign body aspiration that can lead to the frequent delay in diagnosis for several hours, days or even weeks, depending on the location of the foreign body. The final stage will be characterized by mucosal reaction to foreign body which can produce erosion, infection and lead to pneumonia, atelectasis or lung abscess and obstruction of the airway.

Clinical signs and symptoms will depend on the size, shape and the location where the foreign body stuck. 1,3,4 A large smooth foreign body that lodges in larynx or trachea can produce complete airway obstruction and potential to cause a severe respiratory distress.

Laryngeal foreign body usually causes partial airway obstruction and produces changes in vocal qualities, hoarseness or dysphonia, aphonia, paroxysmal cough, dyspnea, and sudden coughing. If obstruction becomes severe, another signs and symptoms will occur such as inspiratory and expiratory stridor, retraction of the respiratory muscles, anxiety and finally the patient will be in cyanosis stage.

Tracheal foreign body gives sign and symptoms such as coughing, dyspnea, stridor, retraction of respiratory muscle and finally cyanosis. Upon carefull physical examination, asthmatoid wheezing, and slap can be heard, and on palpation above the trachea, foreign bodies can be felt with finger. A sharp tracheal foreign body may be imbedded in tracheal mucosa and produced hemoptysis.

A small foreign body like peanuts is commonly located in one of the main bronchus or bronchioles and it will not be diagnosed until the lung complication occurs. The suspected symptoms of bronchial foreign body begins with repetitive dry cough and ends with productive cough, unilateral wheezing, and decreasing or increasing sound of breath. These clinical symptoms might be decreased temporarily by bronchodilator or antitusive drug. Recurrent pneumonia and lung abscess might be resulted from long standing undiagnosed bronchial foreign body.

\section{Radiographic asessment}

As a part of diagnostic procedure, PA and lateral view of neck and chest X-ray can visualize all metallic foreign body. In order to visualize the entire airway from mouth to carina, a lateral chest X-ray with the arms behind the backs, the neck flexed and the heads extended, should be performed. However, in the case of fishbone and chicken bone, a "soft tissue X-ray" technique is required since it is the only appropriate technique that can detect those foreign bodies more accurately. ${ }^{6}$

In peanut aspiration, the radiographic findings are often normal in the first 24 hours of aspiration. ${ }^{2,6}$ According to Soepardi, ${ }^{2}$ radiologic assessment in the first 24 hours of aspiration is associated with only $30,2 \%$ of abnormal findings whereas $69,8 \%$ are normal. These data are based on a PA Chest X-ray that was taken for all patients. In order to verify the presence of a peanut in bronchial tree, two Chest Xrays will be needed for further diagnosis. One is taken at the end of expiration and the other at the end of inspiration. The result from expiratory X-ray 
shows mediastinum shift to unaffected side due to air trapping on the affected side. On inspiration X-ray, the mediastinum will shift back to the affected side. For suspected radiolucent foreign body, the Chest XRay must be retaken after 24 hours.

After 24 hours of aspiration, chest X-ray may reveal obstruction emphysema, atelectasis and consolidation of the lung. ${ }^{6}$ This is also supported by Soepardi's investigation which showed that $92,8 \%$ of radiologic findings were abnormal after 24 hours. $^{2}$

For difficult cases, biplane video fluoroscopy should be performed. The video allows the doctors to discuss the problem without prolong radioactive exposure to the patient.

A radioopaq foreign body ingestion in the esophagus can be detected by plane cervical and chest X-ray. Cervical and chest $\mathrm{X}$-ray in soft tissue condition should be performed to ingested meat and other food that may contain bones. For radioluscent foreign body, esophagogram with a contras media is usually performed. However, the ENT Department Dr. Ciptomangunkusumo Hospital avoids esophagogram using barium as a contras media due to the risk of aspiration of barium.

\section{Management}

Patients with complete airway obstruction, require immediate medical attention. In this situation, Heimlich maneuver which can reduce mortality and emergency tracheotomy, should be performed immediately as a life saving procedure. Before performing tracheotomy, the patient should be given sufficient oxygen in order to improve his (her) condition.

Most of patients arrive at the hospital beyond the acute stage and not in severe respiratory distress. They may still be able to cough, gag and vocalize due to partial obstruction. The ideal treatment is prompt endoscopic removal of foreign body. In this condition, Heimlich maneuver should be avoided because it could lead to complete obstruction. Treatment in the emergency room should be attended only in the most critical cases of respiratory obstruction.

For patients strongly suspected of foreign body aspiration, rigid bronchoscopy should be performed although the clinical sign and symptom are not clear. It should also be done on patients with classic signs and symptoms of aspiration despite normal radiographic findings of the lung.

Patients who suffered foreign body ingestion in their esophagus, esophagoscopy should be performed under general anesthesia with endotracheal intubation.

Removal of foreign body in the upper aerodigestive tract is best performed in an operating room where a well-trained team with an anesthesiologist experienced in foreign body removal and well equipped with proper endoscopic instruments are available. Flexible bronchoscope is only recommended for adults or for removing foreign body in the branch of the bronchus.

\section{Problems in removing foreign body}

\section{Case Report 1}

An 11 years old boy was reported with complaints of cough, dyspnea and hemoptysis for one month before visiting a pulmonologist. According to the boy, his illness was caused by an accident when he was playing with a ballpoint. By accident, he aspirated the ballpoint press button and right after the incident he suffered a repetitive cough.

One month later his mother took him to see a pulmonologist. A chest X-ray examination showed an atelectasis of the right lower lobe. Flexible bronchoscopy was performed but failed because the patient suffered a several episode of bradycardia. The day after, the patient consulted the ENT department and rigid bronchoscopy was then conducted. The rigid bronchoscope was inserted to the left bronchus and surprisingly the foreign body can be seen in there, instead of in the right side. Suddenly the patient got cyanosis. The bronchoscope was withdrawn and then inserted to the right main bronchus to clean the airway. Afterward, the brochoscope was reinserted to the left main bronchus to remove the foreign body by alligator forcep.

It was concluded that coughing has caused foreign body to move from the right to left bronchus. In the management of this problem, chest X-ray should be performed right before the brochoscopy procedure. Rigid bronchoscope is better for removing big foreign body. 


\section{Case Report 2}

A one year old boy was taken by his parents to the hospital with history of sudden cough and cyanosis after he had his porridge contains with nuts. During the examination at the hospital, there was no any sign and symptom of respiratory obstruction. The emergency doctor then released the patient. Five days later, the patient had fever and productive cough. Chest X-ray showed atelectasis at the lower lobe of the right lung. Bronchoscopy was performed after the patient's condition was better. A severe endobronchitis and peanut was found in the bronchus. The patient had to be hospitalized for five days.

In this case, since the diagnostic was not accurate, the complication of foreign body aspiration occurred. Consequently, the patient had to be hospitalized longer than it should be.

\section{Case Report 3}

A 22 years old male admitted to RSCM hospital with the complaint of difficulty in swallowing food and any liquid. The problem occurs when he consciously swallowed an egg-sized stone as an obligation to become a follower of a particular cult. It turned out that the stone was stuck in the esophagus. The examination showed that the patient was also suffering a difficulty in breathing. Rigid esophagoscopy was performed but it was failed to remove the big stone due to the lack of forcep that can grasp the stone. After several attempts, it was decided to perform a servicotomy and it was ultimately succeed.

The conclusion of this case is that the lack of instrument that can grasp an egg-sized foreign body was the main problem. To overcome this problem, a basket forcep with proper size is needed.

\section{Case Report 4}

A 62 years old lady woke up in one morning and found out that she lost her denture. It was suspected that she accidentally swallowed her denture. On that day, her son brought her immediately to Emergency Room at RSCM hospital. A neck-to-chest X-ray was taken and the result showed that the metallic wire of the dentures was at C6. Rigid esophagoscopy was performed by an ENT resident, but it was failed because the wire was stuck in the esophagus wall. Due to the failure to remove the denture, the resident reported to his supervisor. The supervisor suggested to find the duplicate of the denture and discussed how to remove it. After that, the denture can be removed successfully.

Lack of experience and skill in this case is proven to be one of the failure factors in endoscopy procedures. In difficult cases, the surgeon must find the duplicate of the foreign body, study the shape and practice how to remove it easily.

\section{Summary}

Foreign bodies in the upper aerodigestive tract are the most common problems encountered by the otolaryngologist. Yet there might be problems in any handling process. Several problems might occur in the diagnosis process such as: gathering the history of aspiration; unclear signs and symptoms in the clinical examination; and unreliable radiologic expertise. In the management process, problems that might occur are lacking of preparation, incomplete endoscopic instruments and lacking of team's skills.

\section{REFERENCES}

1. Holinger LD. Foreign Bodies of the Airway and Esophagus. In: Holinger LD, Lusk RP, Green CG, eds. Pediatric Laryngology and Bronchoesophagology. Philladelphia: Lippincott-Raven Publishers 1997 : 233-51.

2. Soepardi EA. Chest X-ray Examination of Inhaled Peanut in Children. It is Important. Med J. of Indonesia 1998 : 49-52.

3. Holinger LD. Foreign Bodies of the Larynx, Trachea and Bronchi. In: Bluestone CD Stool SE eds. Pediatric Otolaryngology. Phlladelphia : WB Saunders 1983 : 1302-12.

4. Mohr RM. Endoscopy and Foreign Body Removal. In : Papparella MM, Shumrick DA, Gluckman Jl, Meyerhoff WL, eds. Otolaryngology the $3^{\text {rd }}$ ed. Philladelphia : WB Saunders $1991: 2399-427$.

5. Lamberg PS, Darrow DH, Hollinger LD. Aerodigestive Tract Foreign Bodies in the Older Child and Adolescent. Ann Otol Rhinol Laryngol 1996; 105 : 267-71.

6. Mu LC, Sun DQ, He P. Radiological Diagnosis of Aspirated Foreign Bodies in Children. Review of 343 cases. J Laryngol Otol $1990 ; 104$ : 778-82. 